\title{
MESD wt Allele
}

National Cancer Institute

\section{Source}

National Cancer Institute. MESD wt Allele. NCI Thesaurus. Code C98088.

Human MESD wild-type allele is located in the vicinity of $15 q 25.1$ and is approximately 44 $\mathrm{kb}$ in length. This allele, which encodes LDLR chaperone MESD protein, plays a role in the modulation of the folding of low-density lipoprotein receptor family proteins. A patient with infantile sacrococcygeal teratoma was found to have a balanced chromosomal translocation $\mathrm{t}(12 ; 15)(\mathrm{q13} ; \mathrm{q} 25)$ which fuses this gene and the SENP1 gene. 